\title{
INDEKS KETAHANAN MASYARAKAT PESISIR KECAMATAN KAMPUNG LAUT DALAM MENGHADAPI PENYUSUTAN LAGUNA SEGARA ANAKAN
}

\section{COASTAL COMMUNITY RESILIENCE INDEX OF KAMPUNG LAUT SUB-DISTRICT CONFRONT WITH SHRINKINC OF SEGARA ANAKAN LAGOON}

\author{
Lintang Rahmayana', Wiwandari Handayani ${ }^{1}$ \\ 'Departemen Perencanaan Wilayah dan Kota, Universitas Diponegoro Semarang,
} Info Artikel:

\begin{abstract}
ABSTRAK
Keberadaan laguna segara anakan semakin memprihatinkan. Besarnya laju sedimentasi membuat sedimen yang mengendap diperairan cukup tebal. Selain itu, degradasi lingkungan yang terus terjadi akibat aktivitas masyarakatnya ikut memperburuk keadaan. Penelitian ini bertujuan untuk mengetahui indeks kapasitas ketahanan masyarakat pesisir laguna segara anakan Kecamatan Kampung Laut terhadap penyusutan luasan laguna. Beberapa variabel yang digunakan dalam penelitian in diantaranya adalah ekonomi, manusia, sosial, fisik, dan ekologi. Kelima sektor tersebut memiliki beberapa indikator yang mewakili ketahanan masyarakat laguna di Kecamatan Kampung Laut. Berdasarkan hasil analisis yang dilakukan dapat diketahui bahwa indeks ketahanan masyarakat Kampung Laut termasuk kategori sedang dengan besar indeks 0,52. Namun jika dilihat lebih jauh, ketahanan yang masyarakat miliki saat ini bukan hanya berasal dari faktor internal saja, tetapi adanya faktor eksternal seperti dorongan bantuaan baik dari pemerintah, swasta dan pihak lainnya menjadikan seolah-olah masyarakat telah memiliki ketahanan yang cukup. Namun dibalik hal tersebut, kondisi ini membuat masyarakat menjadi tergantung dengan bantuan sehingga ketahanan yang diperoleh bukan disebabkan masyarakat sudah berdaya namun ada faktor lain yang mempengaruhinya.

Kata Kunci : Ketahanan Masyarakat, Masyarakat Pesisir, Laguna, Kampung Laut, Segara Anakan
\end{abstract}

\begin{abstract}
The existence of Segara Anakan Lagoon increasingly getting worse. The amount of sedimentation rate makes the lagoon has height sediment. In addition the environmental degradation that happen caused by community activity, this can make worsening the situation. This study aims to assess the resilience capacity index of lagoon community in Kampung Laut Subdistrict towards the decline of lagoon area. The variables used in this study are economic, human, social, physical and ecological. The five variables have indicators that can represent the resilience if lagoon community in Kampung Laut subdistrict. Based on the results of the analysis conducted, it can be seen that the resilience index of the Kampung Laut community is in the medium category with a index of 0.52 . However, if this assess more deeply, the resilience of Kampung Laut community might occur because the external factor more dominating than internal factors. This situation makes the Kampung Laut community resilience pretending to have enough resistance than the real condition. Behind this condition, it makes the community dependent on assistance from external parties, so the Kampung Laut community resilience gained not because they are empowered but there are other factors that influence it.
\end{abstract}

Keyword: Community Resilience, Coastal Communities, Laguna, Kampung Laut, Segara Anakan

Copyright $\odot 2016$ GJGP-UNDIP

This open access article is distributed under Creative Commons Attribution (CC-BY-NC-SA) 4.0 International license.

\section{PENDAHULUAN}

Ketahanan dapat diartikan sebagai kapasitas suatu sistem untuk menyerap gangguan dan mereorganisasi saat mengalami perubahan sehingga tetap mempertahankan fungsi, struktur, identitas, dan umpan balik yang sama (Walker dkk, 2004). Hal ini juga dijelaskan oleh Simmie dan Martin (2010), ketahanan 
memiliki arti kemampuan yang dimiliki suatau sistem untuk dapat melompat kembali atau rebound untuk memulihkan diri ke bentuk dan posisi seimbang secara elastis setelah terjadi gangguan atau guncangan yang dapat menekan sistem tersebut.

Salah satu konsep ketahanan yang penting dimiliki oleh setiap wilayah atau daerah adalah ketahanan masyarakat. Hal ini dikarenakan masyarakat merupakan komponen penting yang menentukan perkembangan wilayah atau daerah. Ketahanan masyarakat (community resilience) merupakan konsep ketahanan yang bekerja pada sistem manusia dan sosial (Vogel dkk, 2012). Ketahanan masyarakat dapat pula diartikan sebagai kemampuan individu, kelompok atau komunitas untuk mengatasi tekanan dan gangguan eksternal ketika menjalani perubahan sosial, politik dan lingkungan (Adger, 2000). Ketahanan masyarakat menjadi suatu hal utama yang harus dimiliki bagi daerah dengan tingkat kerentanan tinggi seperti daerah pesisir. Karaktersitik daerah pesisir yang merupakan daratan namun masih dipengaruhi oleh sifat-sifat laut seperti pasang surut, angin laut, perembesan air asin sehingga membuat daerah tersebut memiliki kerentanan tinggi.

Salah satu kabupaten di Jawa Tengah yang tergolong daerah pesisir adalah Kabupaten Cilacap. Delapan kecamatan di Kabupaten Cilacap merupakan daerah pesisir, salah satunya adalah Kecamatan Kampung Laut. Kecamatan Kampung Laut merupakan daratan yang dikelilingi laguna Segara Anakan Samudra Hindia. Kecamatan tersebut memiliki empat desa dengan jumlah penduduk sebesar 17.263 jiwa pada tahun 2016. Keunikan Kecamatan Kampung Laut terletak pada kondisi geografisnya, karena berada di laguna. Hal ini membuat karakteristik masyarakatnya seperti masyarakat pesisir pada umumnya yang bergantung pada sumber daya perairan (laut). Karena keunikannya tersebut maka Kecamatan Kampung Laut dipilih menjadi ruang lingkup wilayah pada penelitian ini, lebih jelasnya dapat dilihat pada Gambar 1.

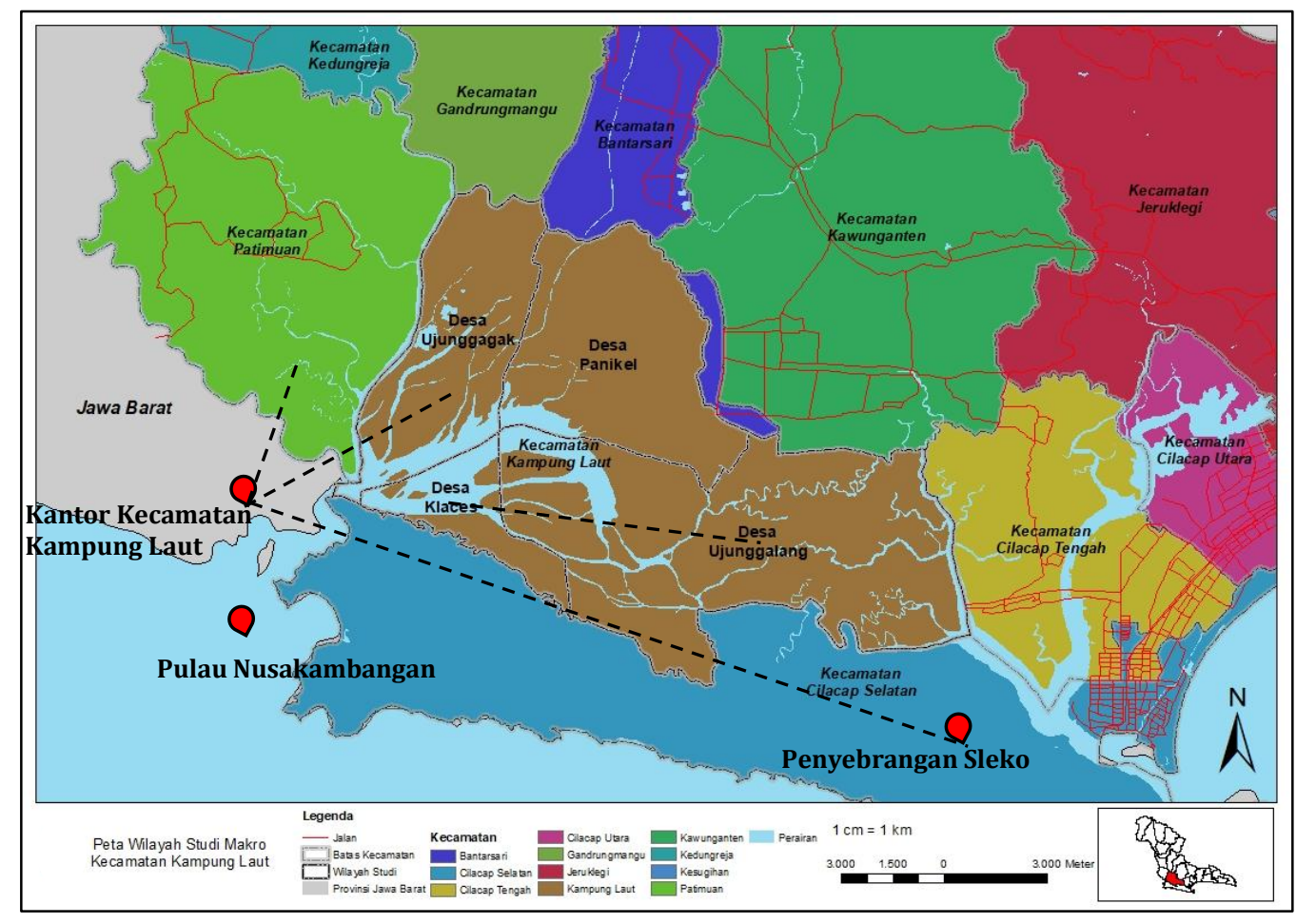

Sumber: RTRW Kabupaten Cialcap 2011-2031

Gambar 1. Peta Administrasi Kecamatan Kampung Laut 
Lebih dari setengah masyarakat Kampung Laut (89\%) berprofesi sebagai nelayan dan petani tambak (BPS, 2017). Alat transportasi utama masyarakatnya adalah transportasi air seperti perahu compreng. Bahkan akses menuju daerah tersebut dari pusat Kota Cilacap harus melalui penyebrangan dermaga dan membutuhkan waktu kurang lebih tiga jam. Dalam memenuhi kebutuhan hidup sehari-hari, masyarakatnya memanfaatkan sumber daya yang ada di laguna. Hal ini membuat ketergantungan masyarakat Kampung Laut pada laguna sangat tinggi. Namun, terjadinya fenomena penyusutan laguna tiap tahun merupkan ancaman bagi masyarakat Kampung Laut.

Perkembangan terbaru menunjukan adanya ancaman yang besar terhadap laguna ini. Diprediksi lagunan akan menghilang akibat beberapa faktor seperti degradasi lingkungan (Sondermann, 2018). Hal ini dibuktikan dengan penyusutan luas laguna sebesar 98,6 ha per tahun yang diikuti dengan penambahan luas daratan (Kementrian Pekerjaan Umum, 2009). Selain itu, terjadinya alih fungsi lahan besar-besaran pada kawasan mangrove memberikan dampak lingkungan yang semakin buruk. Adanya kejadian tersebut selain dapat merusak kestabilan lingkungan, juga mengancam sistem penghidupan masyarakatnya. Menghadapi fenomena menyusutnya laguna, banyak masyarakat Kampung Laut melakukan berbagai macam cara untuk meningkatkan kapasitas ketahanannya dari guncangan tersebut. Pemerintah sebagai salah satu aktor penting tidak hanya menghadapi tantangan untuk mengembangkan dan merealisasikan strategi adaptasi, tetapi juga meningkatkan kapasitas adaptif masyarakat melalui kebijakan yang dibuat (Jordan, 2013). Oleh karena itu pada situasi seperti ini, tindakan efektif yang dapat dilakukan adalah mempersiapkan masyarakat untuk mampu menghadapi dampak negatif yang timbul dengan memperkuat kapasitas ketahanan masyarakat.

Adapun beberapa penelitian terdahulu yang pernah dilakukan oleh Suryawati dkk (2011) dan Dewi dkk (2016) menghasilkan temuan, telah terjadi penyusutan besar-besaran pada laguna segara anakan yang mengancam kestabilan ekosistem dan sistem penghidupan masyarakat Kampung Laut. Hal ini yang menjadi latar belakang penelitian yang akan dilakukan. Penelitian ini juga mengadopsi pada beberapa penelitian yang dilakukan salah satunya oleh Sooriyaarachchi dkk (2018) yaitu melihat model ketahanan perkotaan pesisir di Sri Lanka. Berdasarkan beberapa penelitian tersebut maka penelitian ini akan melihat ketahanan yang dimiliki tiap sektor serta melihat ketahanan tiap desa di Kecamatan Kampung Laut. Selain itu, tujuan dari penelitian ini adalah mengidentifikasi indeks kapasitas ketahanan masyarakat pesisir laguna segara anakan Kecamatan Kampung Laut terhadap penyusutan luasan laguna. Diharapkan dengan adanya penelitian ini dapat menjadi bahan pertimbangan dalam memberikan rekomendasi dan perencanaan yang tepat di daerah tersebut.

\section{DATA DAN METODE}

\subsection{Metode Penelitian}

Metode penelitian ini menggunakan pendekatan mix methods dengan teknik campuran bertahap. Menurut Creswell (2010) strategi ini merupakan strategi dengan peneliti menggabungkan data yang ditemukan dari satu metode dengan metode lainnya. Penelitian ini menggunakan startegi eksplanatoris sekuensial. Metode ini terdiri dari beberapa tahap, pertama mengumpulkan data kuantitatif dan setelah itu mengumpulkan data kualitatif untuk membantu menjelaskan atau mengelaborasi tentang hasil kuantitatif. Latar belakang pemikiran pendekatan ini adalah data kuantitatif dan hasil analisis akan memberikan gambaran umum tentang permasalahan penelitiannya; lebih banyak analisis, khususnya melalui pengumpulan data kualitatif, diperlukan untuk menyempurnakan, memperluas, atau menjelaskan gambaran umum dari hasil kuantitatif.

\subsection{Metode Pengumpulan Data}

Teknik pengumpulan data yang akan dilakukan untuk menjawab pertanyaan dari penelitian ini menggunakan teknik pengumpulan data primer dan data sekunder. Pada data sekunder pengumpulan data dilakukan dengan melalui survey sekunder pada instansi-instansi terkait. Kemudian pengumpulan datanya menggunakan telaah dokumen atau studi perpustakaan. Sedangkan untuk data primer dilakukan dengan 
penyebaran kuesioner kepada masyarakat Kampung Laut menggunakan teknik sampling proportionate stratified random sampling. Selain itu dilakukan pula pengumpulan data dengan cara observasi lapangan dan wawancara mendalam kepada beberapa narasumber baik dari swasta, pemerintah, dan masyarakat.

\subsection{Teknik Analisis Data}

Secara umum dalam penelitian ini teknik analisis data yang digunakan adalah dengan perhitungan indeks ketahanan kemudian dijelaskan lebih dalam dengan hasil verbatim wawancara yang telah diperoleh. Indeks ketahanan merupakan pengukuran perbandingan dari beberapa variabel kerentanan yang berpengaruh dalam suatu kasus tertentu. Menghitung indeks ketahanan masyarakat laguna segara anakan di Kecamatan Kampung Laut menggunakan beberapa variabel terpilih dari hasil studi literatur dan dihubungkan dengan kondisi lapangan yang ada. Pada penelitian ini akan menggunakan lima sektor yang akan digunakan sebagai penentu indeks ketahanan masyarakat. Kelima sektor dan variabel tersebut akan dijelaskan pada gambar di bawah ini.

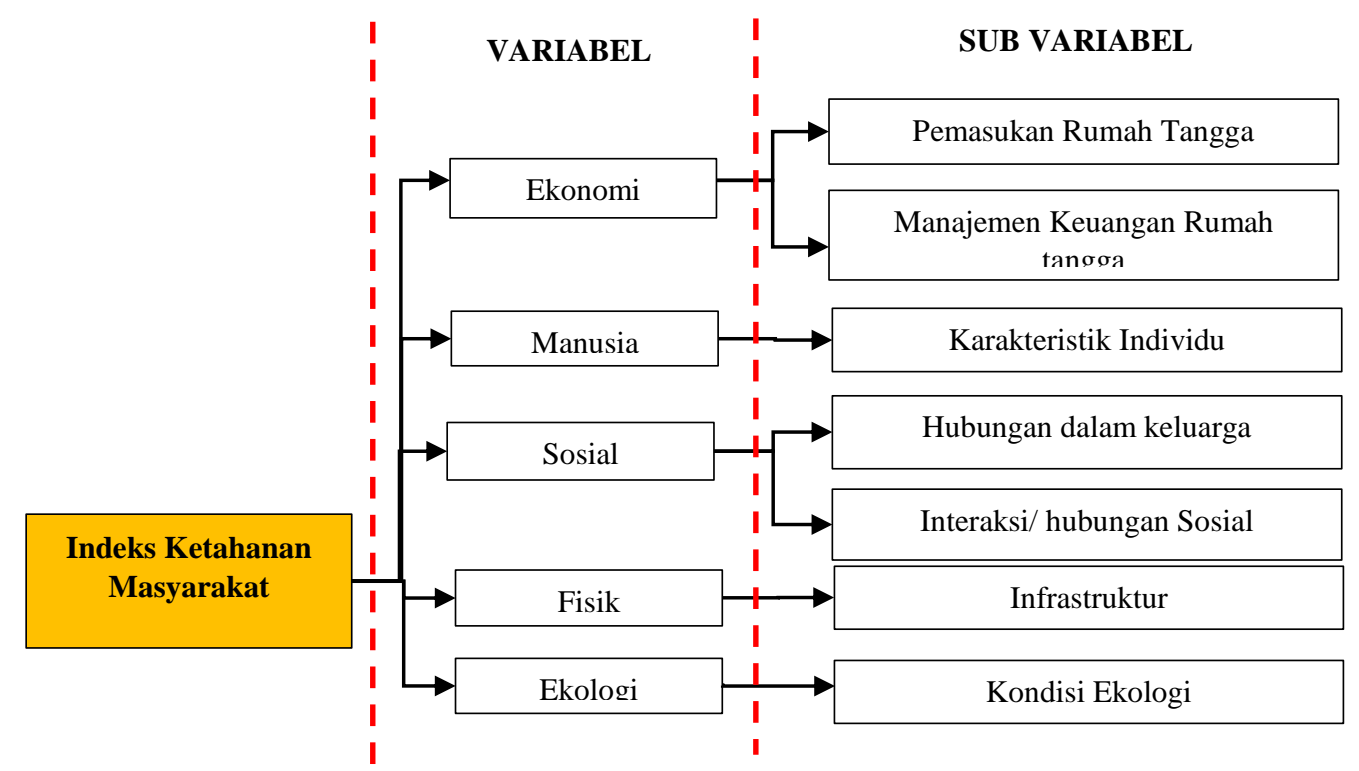

Sumber: Analisis Peneliti, 2019

Gambar 2. Aspek dan Variabel yang Digunakan dalam Penelitian

Nilai indeks yang digunakan dalam penelitian ini berkisar antara 0-1. Hal ini dikarenakan dalam perhitungannya hasil akhir tidak dikali 100. Tujuan adanya perhitungan indeks ini adalah untuk menyamakan jumlah sub indikator agar tiap indikator memiliki jumlah atau besar nilai yang setara. Berdasarkan tabel perhitungan indikator di atas, maka perhitungan indeks yang digunakan adalah menggunakan rumus sebagai berikut. (Sumber: 1. IPM; 2. Fatmasari, 2016; 3. Murty, 2013)

Keterangan:

$$
\text { In }=\frac{X n i-X \min }{X \max -X \min }
$$

$X$ min : nilai capaian atau target minimum

$X$ max : nilai capaian atau target maksimum 


\section{HASIL DAN PEMBAHASAN}

3.1. Indeks Ketahanan Masyarakat Pesisir Laguna Segara Anakan di Kecamatan Kampung Laut dalam Menghadapi Penyusutan Laguna

Ketahanan erat kaitannya dengan keberlanjutan suatau sistem dalam bertahanan lebih dari satu dekade (Martín-Timón dkk, 2014). Menurut Simmie dan Martin (2010), ketahanan memiliki arti kemampuan yang dimiliki suatau sistem untuk dapat melompat kembali atau rebound untuk memulihkan diri ke bentuk dan posisi seimbang secara elastis setelah terjadi gangguan atau guncangan yang dapat menekan sistem tersebut. Berdasarkan pengertian tersebut, mempersiapkan masyarakat yang tahan guncangan merupakan hal yang paling memungkinkan untuk dilakukan pada kasus penyusutan laguna di Segara Anakan. Hal ini disebabkan oleh fenomena penyusutan laguna merupakan kejadian alam yang tidak dapat dihandari namun hanya dapat diperlambat, sehingga upaya penyelamatan laguna membutuhkan waktu dan biaya yang tidak sedikit

Total nilai indeks ketahanan masyarakat Kampung Laut adalah 0,52 dengan kategori sedang. Berdasarkan jenisnya, ketahanan yang dimaksud dalam kasus ini adalah kemampuan untuk mengantisipasi, mencegah dan mempersiapkan efek buruk yang dibawa oleh peristiwa berikutnya (Cho dkk, 2011). Untuk mengatasi dan mempersiapkan efek buruk yang terjadi, maka akan lebih baik jika melihat tingkat ketahanan peraspek yang berhubungan dengan sistem penghidupan masyarakat. Pada penelitian ini aspek yang dimaksud adalah ekologi, ekonomi, sosial, manusia dan fisik. Berikut ini adalah nilai indeks ketahanan masyarakat peraspek.

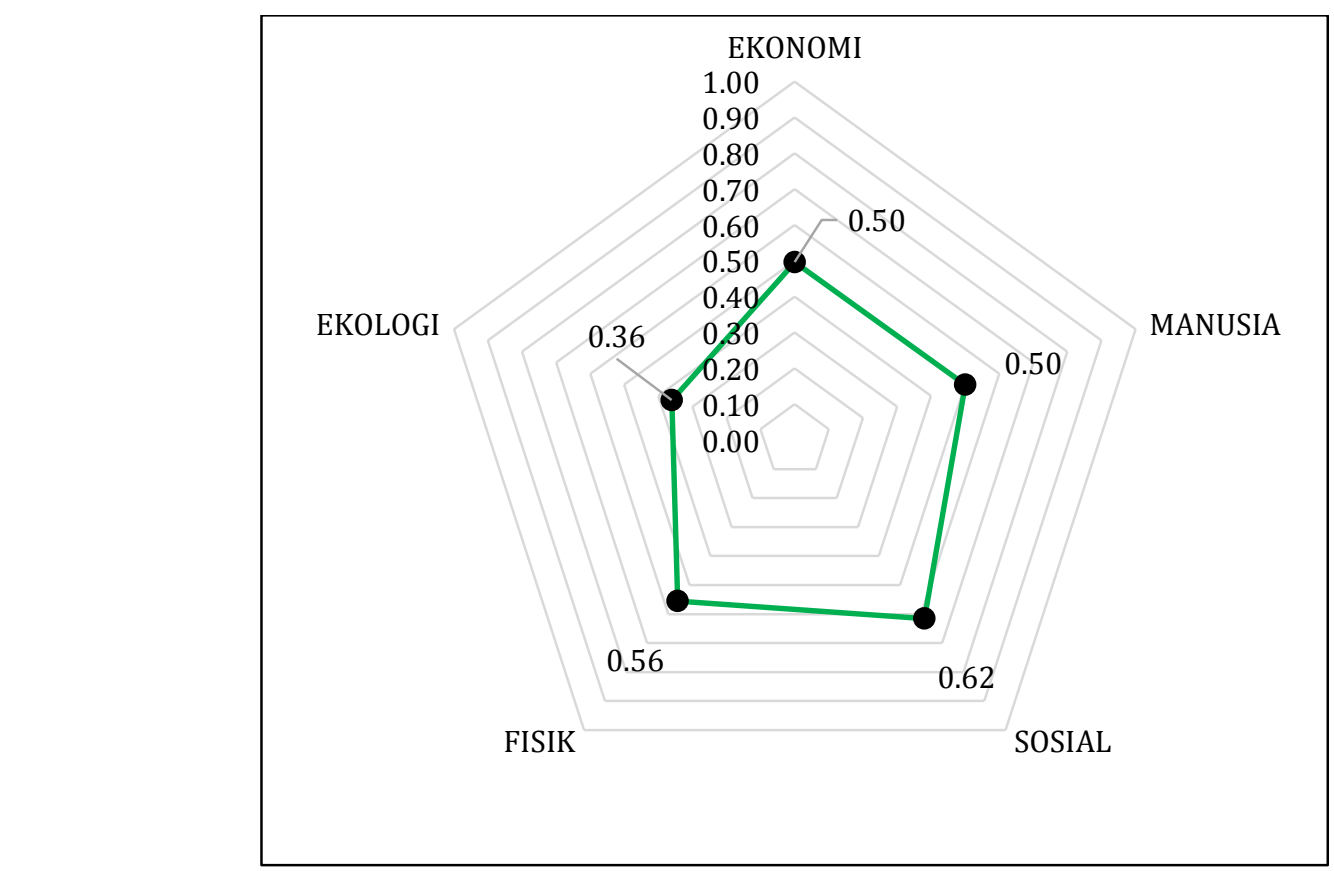

Sumber: Analisis Peneliti, 2019

Gambar 3. Indeks Ketahanan Masyrakat Kampung Laut per Aspek

Pada di atas, dapat terlihat bahwa aspek yang termasuk klasifikasi rendah adalah aspek ekologi dan aspek dengan klasifikasi tertinggi adalah sosial. Untuk ketiga aspek lainnya yaitu ekonomi, manusia, dan fisik memiliki klasifikasi sedang. Dari hasil tersebut dapat diartikan bahwa guncangan yang terjadi pada aspek ekologi masih dirasakan oleh masyarakat Kampung Laut. Namun masyarakat belum memiliki ketahanan yang baik untuk dapat menghadapi dan mengurangi dampak guncangan pada aspek ekologi.

Rendahnya aspek ekologi dibandingkan aspek lainnya menimbulkan beberapa dugaan yaitu adanya bentuk-bentuk ketahanan yang masyarakat lakukan disektor lainnya (selain ekologi) memberikan dampak 
negatif bagi sektor ekologi. Dugaan lainnya adalah sikap kepedulian masyarakat pada lingkungan masih rendah dikarenakan beberapa hal yaitu keterbatasan pengetahuan masyarakat memahami arti penting elemen ekologi yang ada di daerah mereka serta upaya yang tepat untuk menghadapi guncangan yang terjadi pada sektor ekologi.

Tujuan ketahanan selain yang dijelaskan di atas adalah dapat pula menciptakan kondisi suatau daerah menjadi lebih ideal, stabil, dan berkelanjutan (Lessy, 2016). Pembangunan berkelanjutan suatu daerah dapat dilihat dari aspek sosial, ekonomi dan ekologinya (Wreford dkk, 2010). Oleh karena itu, dalam penelitian ini mengidentifikasi bentuk ketahanan yang masyarakat lakukan dengan melihat keberlanjutan dari beberapa aspek yang mempengaruhinya. Berdasarkan gambar di atas, dapat dilihat bahwa pembangunan di Kampung Laut masih belum berkelanjutan. Hal ini dapat terlihat bahwa belum adanya keseimbangan antar aspeknya yang dibuktikan dari hasil indeks ketahanan masyarakatnya. Terdapat salah satu aspek yang berkorban untuk kepentingan aspek lainnya. Penjelasan mengenai tiap aspek selanjutkan akan lebih dibahas berikut ini.

\section{a. Aspek Ekonomi}

Pada sektor ekonomi memiliki nilai yang sama dengan sektor manusia yaitu sebesar 0,50 dan termasuk dalam klasifikasi sedang. Ketahanan masyarakat pada sektor ekonomi ini dapat dilihat dari pemasukan rumah tangga dan manajemen keuangan rumah tangga. Pada kuesioner yang telah disebar maka didapatkan informasi bahwa hampir setengah dari keseluruhan responden mengatakan mereka saat ini hidup dengan cara memanfaatkan laguna. Hal ini menandakan sebagian besar masyarakat Kampung Laut menganggantungkan perekonomiannya pada laguna, sehingga kondisi laguna berpengaruh pada penghidupan masyarakat. Hal ini dibuktikan pula dari data statistik kependudukan berikut ini.

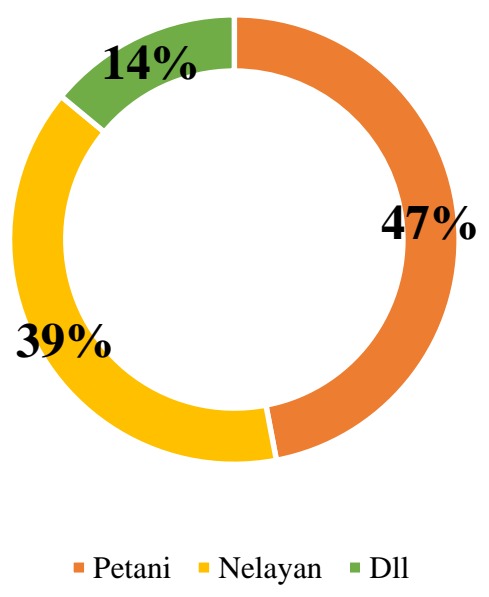

Sumber: BPS, 2016

Gambar 4. Prosentase Jumlah Penduduk Permata Pencaharian di Kecamatan Kampung Laut Tahun 2016

Namun, terjadinya penurunan jumlah produksi perikanan yang mengakibatkan penurunan pemasukan masyarakat membuat masyarakat Kampung Laut mencoba mempelajari keahlian lain seperti pembuatan kerajinan bambu, pembuatan sapu lidi, pengolahan makanan laut dll. Keahlian tersebut didapatkan dengan mempelajari sendiri dari masyarakat sekitar, belum ada lembaga khusus yang secara formal mengajarkan.

"Yaa... kami sih para istri gini-gini aja lah mba cuma ibu rumah tangga, sekarang ini udah mulai mba belajarbelajar anyaman ini, buat sapu lidi, keset lumayan hasilnya buat bantu-bantu pemasukan sih" (NN/W5/27-112018/13-14) 
Namun hal ini hanya dilakukan oleh penduduk perempuan saja atau istri. Sedangkan penduduk laki-laki atau suami mata pencaharian utamanya adalah sebagai nelayan. Jika musim paceklik atau hasil tangkapan tidak ada maka mereka lebih memilik untuk menebang pohon Mangrove atau Albasia di Nusakambangan. Adanya penurunan jumlah pendapatan membuat istri sebagai kaum perempuan ikut membantu dalam mencari nafkah sebagai tambahan pemasukan. Sedangkan dari segi manajemen keuangan rumah tangga, masyarakat Kampung Laut tergolong belum baik karena hanya sebagian masyarakat yang memiliki tabungan dan merasa perlu untuk menabung.

Secara umum, upaya yang dilakukan masyarakat Kampung Laut untuk meningkatkan ketahanan ekonomi masih belum optimal. Terdapat maladaptasi yang dilakukan untuk mengatasi guncangan diaspek ekonomi sehingga merugikan aspek ekologi. Dalam hal ini masyarakat yang tangguh bergantung pada mata pencaharian yang berkelanjutan (Chuang dkk, 2018). Adanya kondisi tersebut dapat disimpulkan bahwa masyarakat Kampung Laut masih belum memiliki ketahanan yang baik pada aspek ekonomi.

b. Aspek Manusia

Aspek manusia memiliki nilai yang sama dengan aspek ekonomi yaitu dengan klasifikasi sedang sebesar 0,50. Pada aspek ini melihat ketahanan masyarakat dari karakteristik dan pola pikir suatu individu sehingga secara tidak langsung dapat mempengaruhi tindakan yang dilakukan pada aspek lainnya. Misalnya, pada aspek ini didapatkan informasi bahwa hanya sebagian masyarakat yang memiliki keinginan untuk mengembangkan diri, selain itu tidak semua masyarakat memiliki pola pikir kedepan dengan memiliki rencana atau visi kedepan misalnya dengan berpindah tempat tinggal, beralih profesi, anak mendapat pendidikan setinggi-tingginya, upaya pelestarian lingkungan, dll. Kondisi ini dapat dikarenakan latar belakang pendidikan masyarakat Kampung Laut masih tergolong rendah.

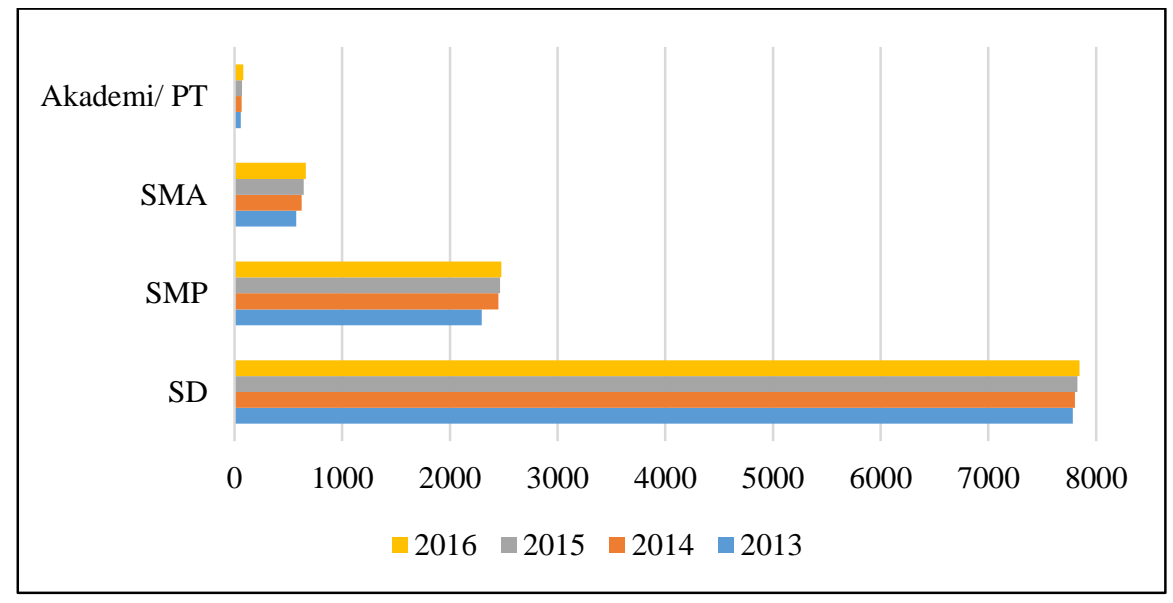

Sumber: BPS, 2016

Gambar 5. Perkembangan Jumlah Penduduk per Tingkat Pendidikan Tahun 2016

Masyarakat dinilai sudah memiliki ketahanan dalam aspek ini jika memiliki pola pikir dan visi atau perencanaan kedepan. Hal ini dikarenakan dampak penyusutan laguna tidak muncul secara langsung melainkan perlahan-lahan dan membutuhkan proses. Oleh karena itu penanganan yang dilakukan akan lebih efektif jika bersifat jangka panjang. Pola pikir masyarakat yang sudah berfikir kedepan akan sangat mempengaruhi bentuk-bentuk ketahanan yang mereka lakukan untuk dapat bertahan dari guncangan tersebut. Oleh karena itu dalam kasus ini aspek manusia memiliki peranan penting karena dapat mempengaruhi bentuk ketahanan yang digunakan pada aspek lainnya.

Pentingnya peningkatan aspek manusia sehingga dapat mendorong aspek lainnya, juga terjadi pada kasus ketahanan di pesisir Sri Lanka. Dari hasil penelitian yang dilakukan oleh Sooriyaarachchi dkk (2018) menyebutkan bahwa kunci sukses dalam menerapkan kerangka konsep ketahanan di masyarakat pesisir 
bukan hanya terletak pada kelembagaan atau pemerintahannya saja, namun pada pengetahuan masyarakatnya akan rasiko dan bahaya yang ada pada lingkungannya juga menjadi suatu hal yang penting. Dari pernyataan tersebut dapat disimpulkan bahwa hal

\section{c. Aspek Sosial}

Aspek sosial merupakan aspek dengan nilai ketahanan tertinggi. Pada aspek ini melihat hubungan yang terjalin antara individu dengan komunitas atau pihak luar (Reivich dan Shatte, 2002). Hubungan yang terjalin antara masyarakat dalam satu desa di Kecamatan Kampung Laut sangat erat. Hal ini dapat dikarenakan kondisi geografis yang ada di daerah tersebut membuat aksesibilitas antar desa menjadi terbatas dan terisolir. Kegiatan gotong royong menjadi hal yang sangat penting di daerah tersebut terutama saat perbaikan bangunan yang rusak, pembangunan rumah, acara pernikahan, dll.

"Jadi tiap desa itu rata-rata punya kekerabatannya yang kuat. Karena disitu kan antar desa letaknya jauh dan terpisah-pisah. Seperti klaces kan sendiri terus yang lain sendiri sudah seperti pulau. Hal ini yang membuat kekerabatan kuat. Karena mereka yaa jarang bergaul dengan lainnya. Tidak sesering orang darat untuk bisa bergaul diluar teritorinya karena saling dekat" (PC/W3/27-11-2018/181-187)

Masyarakat di kecamatan Kampung Laut dapat saling mengandalkan satu dengan lainnya, termasuk dalam hal peminjaman uang untuk pemenuhan hidup sehari-hari atau sebagai modal usaha. Keterbatasan fasilitas yang ada di daerah tersebut membuat hubungan antar masyarakatnya menjadi erat. Namun disisi lain ego masing-masing desa sangat besar sehingga sering terjadi konflik antar desa. Konflik yang terjadi seperti perebutan bantuan yang diberikan pihak luar dan perebutan daerah kekuasaan (untuk mencari ikan dan pemanfaatan lahan timbul). Namun eratnya hubungan masyarakat dalam satu desa membuat ketahanan yang dimiliki menjadi kuat terutama dari segi aspek sosial. Masyarakat saling tolong menolong dalam menghadapi guncangan. Selain itu adanya fenomena penyusutan laguna membuat masyarakat Kampung Laut banyak menerima bantuan baik dari pemerintah atau pihak swasta luar lainnya. Berikut ini adalah beberapa pihak swasta luar yang pernah menjalin kerja sama dengan Kampung Laut.

- Asian Development Bank (ADB)

- Pertamina Refinery Unit (RU) IV

- YSBS (Yayasan Sosial Bina Sejahterah)

- LSM Serikat Tani Mandiri (SeTAM)

- Kemenristek

- Ocean and Coastal Policy Program Duke University

- Institut Pertanian Bogor (IPB)

- Universitas Indonesia

- Universitas Soedirman

- Fakultas Perikanan Universitas Diponegoro

- DII

\section{d. Aspek Fisik}

Pada aspek fisik merupakan aspek dengan nilai ketahanan tertinggi kedua setelah aspek sosial. Hal ini dikarenakan masyarakat umumnya sudah dapat beradaptasi dengan baik pada aspek fisik ditunjukan dengan peninggian rumah yang dilakukan untuk menghindari banjir dan rob (Hegger dkk, 2016). Selain itu masyarakat memiliki cara tersendiri dalam menghadapi keterbatasan fasilitas yang ada. Misalnya dalam pembangunan rumah, meskipun pondasi rumah tidak ditanan, namun masyarakat berupaya untuk membuat rumah lebih kokoh dengan menggunakan material seperti semen, pasir dan batu bata.

Pengangkutan bahan bangunan dari daratan (Cilacap) menuju Kampung Laut dilakukan secara bersama menggunakan perahu yang mereka miliki secara pribadi. Contoh lainnya adalah pembuatan jaringan listrik masuk desa dimana pengangkutan bahan material seperti tiang listrik dilakukan bersama-sama menggunakan perahu. Adanya hubungan yang erat antar masyarakatnya membuat daerah tersebut 
memiliki cara tersendiri dalam menghadapi keterbatasan fasilitas yang dimiliki sehingga ketahanan dari aspek fisikpun tergolong tinggi.

e. Aspek Ekologi

Berdasarkan Gambar 3 sektor ekologi merupakan sektor yang nilai ketahanannya paling rendah dibandingkan sektor lainnya. Hal ini dikarenakan sektor ekologi merupakan sektor yang paling banyak mengalami kerugian akan adanya penysutan laguna dan memberikan dampak negatif dimasyarakat. Upaya yang dilakukan masyarakat untuk meningkatkan ketahanan di aspek tersebut masih kurang. Hal ini dapat dikarenakan tingkat kepedulian masyarakat yang rendah dan kurangnya pengetahuan mengenai upaya yang tepat untuk menghadapi guncangan (Proag, 2014). Degradasi lingkungan terus terjadi baik dari faktor alam dan masyarakatnya. Upaya-upaya yang masyarakat lakukan untuk dapat bertahan hidup sedikit banyak menyumbang kerusakan ekologi di Kawasan Kampung Laut. Misalnya pembukaan lahan pada hutan mangrove, penangkapan biota laut yang masih menjadi bibit sehingga seiring berjalannya waktu akan punah.

"Yaa masih banyak mba. Sebenernya sih kita sadar mba itu ga bagus. Tapi gimana ya kita mau hidup dari apa. Misalnya ada kepiting bunting yaa gimana ga kita tangkep laah enak di jual mahal” (NN/W5/27-11-2018/79-81)

Beberapa upaya yang dilakukan untuk dapat meningkatkan ketahanan diaspek ekonomi secara tidak langsung dapat memperburuk kondisi ekologi yang ada. Namun hal ini belum disadari masyarakat sehingga tidak ada upaya khusus yang dilakukan. Masyarakat masih belum paham dampak yang ditimbulkan dari kerusakan ekologi dapat menjadi ancaman baru pada aspek lainnya. Beberapa kegiatan pelestarian lingkungan di Kecamatan Kampung Laut sudah dilakukan oleh beberapa lembaga, namun hal ini belum memberikan hasil dan tidak ada pelibatan masyarakat di dalamnya. Perlu adanya upaya yang dilakukan untuk menyadarkan masyarakat akan pentingnya ekologi bagi keberlanjutan hidup mereka.

\subsection{Indeks Ketahanan Masyarakat Perdesa di Kecamatan Kampung Laut dalam Menghadapi Penyusutan}

Laguna

Kecamatan Kampung Laut terdiri dari empat desa. Keempat desa tersebut memiliki besar indeks ketahana yang berbeda-beda. Terdapat banyak faktor yang mempengaruhi hal tersebut baik dari internal dan eksternal (Crespo dkk, 2013). Perhitungan ketahanan tiap desa memiliki rumus yang sama saat perhitungan ketahanan untuk satu Kecamatan Kampung Laut. Untuk nilai ketahanan tiap desa dapat dilihat pada Gambar 6. Desa terendah yang memiliki indek ketahanan penduduknya adalah Desa Klaces dan yang tertinggi adalah Desa Ujungalang.

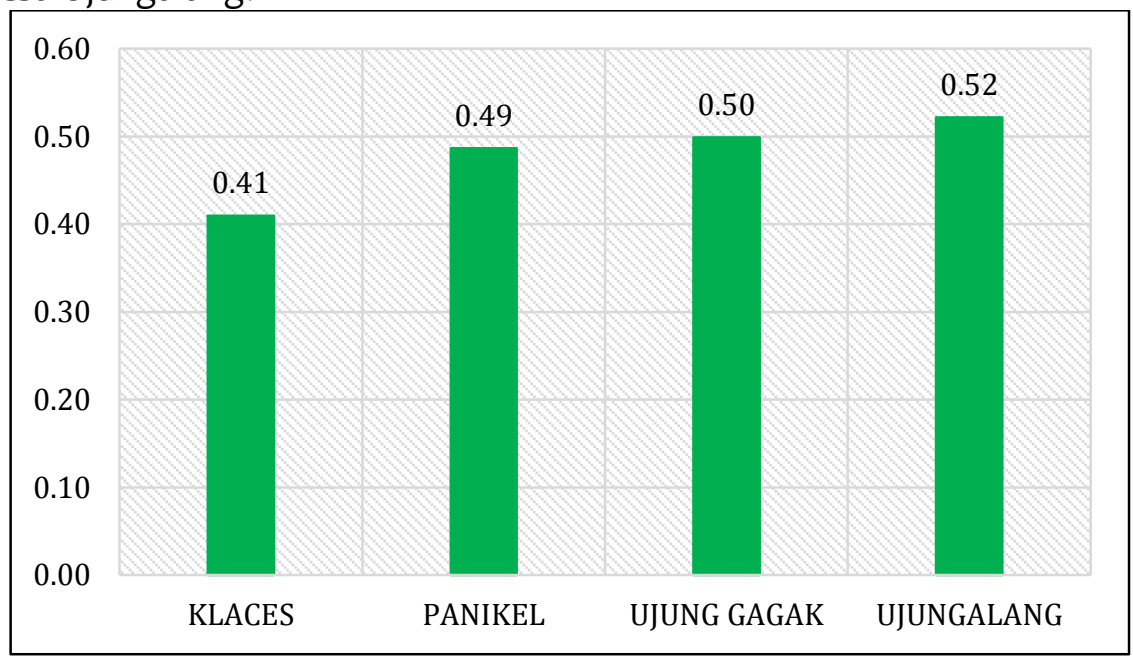

Sumber: Analisis Peneliti, 2019

Gambar 6. Indeks Ketahanan Tiap Desa di Kecamatan Kampung Laut 
Rahmayana, Handayani/ Jurnal Pembangunan Wilayah dan Kota, Vol 15 No.2, 2019, 96-107 Doi: https://doi.org/10.14710/pwk.v15i2.22157

Tabel 1. Indeks dan Klasifikasi Ketahanan Masyaakat Kampung Laut per Desa

\begin{tabular}{lllllllllllll}
\hline & \multicolumn{2}{l}{ Ekonomi } & \multicolumn{2}{l}{ Manusia } & \multicolumn{2}{c}{ Sosial } & & \multicolumn{2}{c}{ Fisik } & & \multicolumn{2}{c}{ Ekologi } \\
\hline Klaces & 0,38 & Rendah & 0,3 & Rendah & 0,66 & Tinggi & 0,29 & Rendah & 0,43 & Sedang \\
Panikel & 0,47 & Sedang & 0,5 & Sedang & 0,63 & Tinggi & 0,42 & Sedang & 0,41 & Sedang \\
Ujung Gagak & 0,47 & Sedang & 0,38 & Rendah & 0,61 & Tinggi & 0,6 & Tinggi & 0,44 & Sedang \\
Ujungalang & 0,49 & Sedang & 0,5 & Sedang & 0,59 & Sedang & 0,55 & Sedang & 0,48 & Sedang \\
Rata-rata & 0,45 & Sedang & 0,42 & Sedang & 0,62 & Tinggi & 0,47 & Sedang & 0,44 & Sedang \\
\hline
\end{tabular}

Sumber: Analisis Peneliti, 2019

Indeks ketahanan masyarakat selain dapat dilihat secara keseluruhan maka dapat pula diketahui indeks ketahanan per sektor atau pervariabel yang digunakan dalam penelitian ini. Tiap desa memiliki besar indeks ketahanan pervariabel yang berbeda satu dengan yang lainnya. Untuk lebih jelasnya dapat dilihat pada diagram di bawah ini.

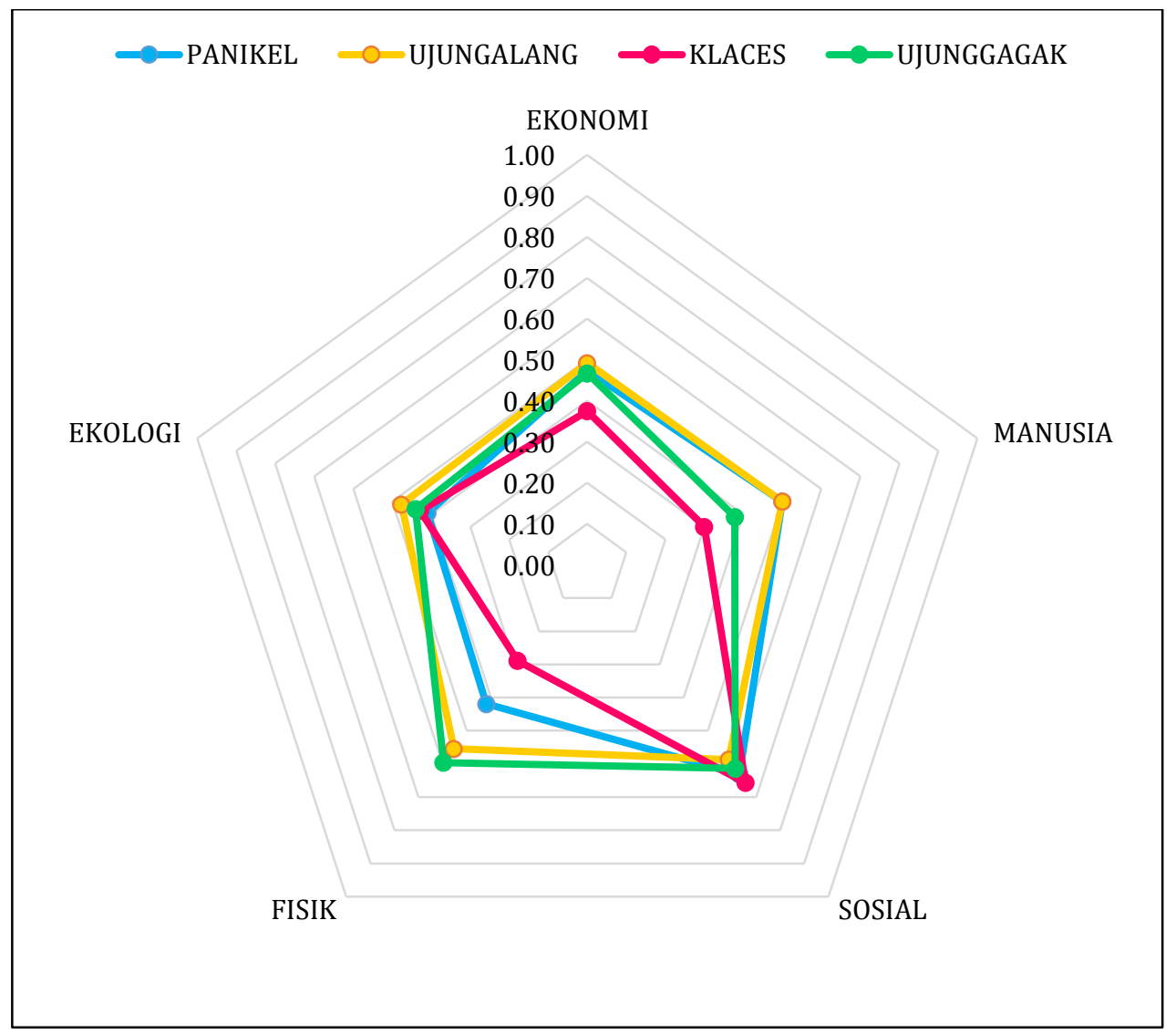

Sumber: Analisis Peneliti, 2019

Gambar 7. Indeks Ketahanan Masyarakat Kecamatan Kampung Laut Per Desa dan Per Variabel

Dari gambar 7 dapat terlihat bahwa perbedaan yang cukup jauh dilihat pada aspek fisik dan manusia. Sedangkan pada aspek ekologi dan sosial rata-rata tiap desa memiliki besar yang sama. Adanya perbedaan nilai yang cukup jauh antar desa dikarenakan kondisi yang ada pada desa tersebut. Dari gambar di atas dapat disimpulkan bahwa ketahanan yang dimiliki masyarakat tiap desa masih perlu didorong terutama dari aspek fisik. Keeratan hubungan antar masyarakat diaspek sosial dapat mempengaruhi cara masyarakat untuk dapat bertahan diaspek fisik seperti yang telah dijelaskan pada sub bab sebelumnya. Namun dalam diagram 
ini aspek sosial tiap desa memiliki ketahanan yang sama. Hal ini dikarenakan adanya hubungan yang baik antara masyarakat dengan pihak atau lembaga luar seperti pemerintah dan swasta dengan mengharapkan dapat diberi bantuan. Kondisi ini yang menyebabkan tiap desa memiliki ketahanan sosial yang tinggi meskipun tingkat hubungan antar masyarakatnya berbeda-beda tiap desa.

Hal ini pun terjadi pada aspek ekonomi dan manusia. Tiap desa memiliki tingkat ketahanan yang berbeda-beda pada aspek tersebut. Dari gambar 7 dapat diartikan bahwa tiap desa belum semua masyarakatnya memiliki pola pikir kedepan, sehingga hal ini pun berdampak pada ketahanan yang ada di sektor ekonomi dan beberapa sektor lainnya. Selain itu perbedaan pola pikir dan hubungan kekerabatan tiap desa juga ikut mempengaruhi besarnya nilai-nilai tiap aspek. Oleh karena itu hal ini menyebabkan perbedaan nilai yang cukup jauh antar aspek pada tiap desa. Sedangkan untuk sektor ekologi tiap desa memiliki besar ketahanan yang secara umum sama. Hal ini dapat diambil kesimpulan bahwa bentuk ketahanan yang dilakukan masyarakat tiap desa disektor ekologi sama, yaitu mayoritas masyarakat masih belum paham akan pentingnya aspek ekologi dapat mempengaruhi aspek lainnya. Hal ini dapat terlihat bahwa aspek ekologi merupakan aspek dengan nilai ketahanan terendah jika dibandingkan dengan aspek lainnya.

\section{KESIMPULAN}

Berdasarkan hasil tujuan dari penelitian ini, maka diketahui bahwa tingkat ketahanan masyarakat Kampung Laut termasuk dalam kategori sedang dengan besar nilai 0,52. Namun jika dilihat lebih jauh, bentuk ketahanan yang masyarakat miliki saat ini bukan hanya berasal dari faktor internal saja, tetapi adanya faktor eksternal seperti dorongan bantuan baik dari pemerintah, swasta dan pihak lainnya menjadikan seolah-olah masyarakat telah memiliki ketahanan yang cukup. Hal ini dapat dilihat pada besarnya tingkat ketahanan aspek sosial terutama pada hubungan individu dengan pihak luar. Hubungan yang terjalin dimanfaatkan sebagai sarana dalam penerimaan bantuan. Kondisi seperti ini membuat sifat masyarakat menjadi tidak mandiri dan mempengaruhi ketahanan diberbagai aspek.

Dari kelima aspek yang menjadi variabel dalam penelitian ini, aspek yang paling mempengaruhi ketahanan masyarakat Kampung Laut adalah aspek manusia. Dengan pembentukan pola pikir kedepan, maka akan mempengaruhi tindakan serta perencanaan yang dilakukan masyarakat. Selain itu, rendahnya pendidikan yang masyarakat miliki saat ini juga berpengaruh pada pemilihan bentuk kapasitas ketahanan yang dilakukan. Jika peningkatan ketahanan pada aspek manusia dilakukan maka hal ini dapat pula meningkatkan ketahanan pada aspek lainnya.

Rendahnya pengetahuan dan kepedulian masyarakat pada lingkungan menyebabkan aspek ekologi memiliki ketahanan terendah. Selain itu, bentuk ketahanan pada beberapa aspek seperti maladaptasi yang dilakukan memberikan dampak negatif. Pada kasus ketahanan masyarakat Kampung Laut, ekologi merupakan aspek yang paling banyak dikorbankan untuk kepentingan aspek lainnya. Oleh karena itu dapat dikatakan bahwa ketahanan masyarakat Kampung Laut mempengaruhi konsep sustainable development di daerah tersebut. Hal ini dibuktikan dengan masyarakat lebih mengedepankan salah satu aspek dibandingkan aspek lainnya.

\section{PERNYATAAN RESMI}

Pada kesempatan ini penulis bermaksud menyampaikan rasa terima kasih kepada pihak-pihak yang selama ini telah mendukung, mendoakan, memotivasi serta membimbing dalam menyelesaikan Tesis yang berjudul “Ketahanan Masyarakat Pesisir Kecamatan Kampung Laut Dalam Menghadapi Penyusutan Laguna Segara Anakan" dengan lancar. Ucapan terimakasih sebesar - besarnya kami sampaikan kepada pihak-pihak yang telah membantu dalam pembuatan Proposal Tesis ini hingga dapat selesai, yaitu:

1. Dosen Pembimbing yang telah membimbing dan memberikan masukan selama proses penyusunan Proposal Tesis yaitu, Dr-ing. Wiwandari Handayani, ST, MT, MPS serta dosen Penguji yaitu Dr. -Ing. Prihadi Nugroho, ST, MT, MPP dan Dr. Ir. Artiningsih, MSi. 
Rahmayana, Handayani/ Jurnal Pembangunan Wilayah dan Kota, Vol 15 No.2, 2019, 96-107

Doi: https://doi.org/10.14710/pwk.v15i2.22157

2. Orangtua dan keluarga yang telah memberikan dukungan baik dukungan material hingga dukungan moril,

3. Segenap teman - teman MPWK angkatan 2017, yang telah memberikan dukungan dan semangat,

4. Semua pihak yang telah membantu dalam menyusun Tesis ini yang tidak dapat kami sebutkan satu per satu.

\section{REFERENSI}

Adger, W. N., Hughes, T. P., Folke, C., Carpenter, S. R., \& Rockström, J. (2005). Social-ecological resilience to coastal disasters. Science, 309(5737), 1036-1039.

Cho, A., Willis, S., \& Stewart-Weeks, M. (2011). The resilient society: innovation, productivity, and the art and practice of connectedness. Cisco Internet Business Solutions Group. IBSG.

Chuang, W. C., Garmestani, A., Eason, T. N., Spanbauer, T. L., Fried-Petersen, H. B., Roberts, C. P., ... \& Gunderson, L. (2018). Enhancing quantitative approaches for assessing community resilience. Journal of environmental management, 213, 353-362.

Creswell, J. W. (2010). Mapping the developing landscape of mixed methods research. SAGE handbook of mixed methods in social \& behavioral research, 2, 45-68.

Dewi, R., Zainuri, M., Anggoro, S., \& Winanto, T. (2016). Analisis Perubahan Lahan Kawasan Laguna Segara Anakan Selama Periode Waktu (1978-2016) Menggunakan Satelit Landsat Multitemporal. Omni-Akuatika, 12(3).

Fatmasari, D. (2016). Analisis Sosial Ekonomi Dan Budaya Masyarakat Pesisir Desa Waruduwur, Kecamatan Mundu, Kabupaten Cirebon. Al-Amwal: Jurnal Ekonomi dan Perbankan Syari'ah, 6(1)

Hegger, D. L., Driessen, P. P., Wiering, M. A., Van Rijswick, H. F., Kundzewicz, P., Matczak, A., ... \& Larrue, C. (2016). Toward more flood resilience: Is a diversification of flood risk management strategies the way forward?.

Jordan, J. V. (2013). Relational resilience in girls. In Handbook of resilience in children (pp. 73-86). Springer, Boston, MA.

Lessy, M. R. (2016, October). Kapasitas Adaptif Masyarakat di Wilayah Pesisir Terhadap Bencana (Studi Kasus Bencana Banjir di Kelurahan Bastiong Karance Kota Terante). In Prosiding Seminar Nasional Kemaritiman dan Sumber Daya Pulau-Pulau Kecil, Vol. 1, No. 1.

Martín-Timón, I., Sevillano-Collantes, C., Segura-Galindo, A., \& del Cañizo-Gómez, F. J. (2014). Type 2 diabetes and cardiovascular disease: have all risk factors the same strength?. World journal of diabetes, 5(4), 444.

Murti, R. (2013). Ecosystems and disaster risk reduction in the context of the Great East Japan Earthquake and Tsunami: a scoping study Report to the Keidanren Nature Conservation Fund.

Proag, V. (2014). The concept of vulnerability and resilience. Procedia Economics and Finance, 18, 369-376.

Reivivh, Karen \& Andrew, Shatte. 2002. The Recilience Factor. New York: Broadway Books

Simmie, J., \& Martin, R. (2010). The economic resilience of regions: towards an evolutionary approach. Cambridge journal of regions, economy and society, 3(1), 27-43.

Sondermann, D. (2018). Towards more resilient economies: the role of well-functioning economic structures. Journal of Policy Modeling.

Sooriyaarachchi, P., Sandika, A. L., \& Madawanarachchi, N. (2018). Coastal community resilience level of Tsunami prone area: a case study in Sri Lanka. Procedia engineering, 212, 683-690.

Vogel, A., Scherer-Lorenzen, M., \& Weigelt, A. (2012). Grassland resistance and resilience after drought depends on management intensity and species richness. PloS one, 7(5), e36992.

Walker, B., Gunderson, L., Kinzig, A., Folke, C., Carpenter, S., \& Schultz, L. (2006). A handful of heuristics and some propositions for understanding resilience in social-ecological systems. Ecology and society, 11(1).

Wreford, A, Aakre, S., Banaszak, I., Mechler, R., Rübbelke, D, \& Kalirai, H. (2010). Financial adaptation to disaster risk in the European Union. Mitigation and Adaptation Strategies for Global Change, 15(7), 721-736. 